\title{
An Unusual Case of Invasive Encapsulated Papillary Carcinoma of the Breast: A Case Report
}

\section{Um Caso Raro de Carcinoma Papilar Encapsulado Invasivo da Mama: Um Caso Clínico}

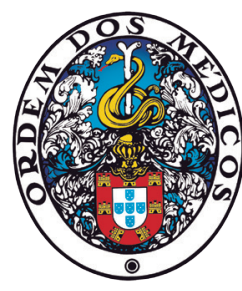

\author{
Xavier de SOUSA $\rrbracket^{*}, 1$, Pedro Santos FERREIRA*,1, Isabel Lopes MARTINS ${ }^{1}$, Manuel Vitor RIGUEIRA ${ }^{1}$ \\ Acta Med Port 2020 Dec;33(12):838-842 - https://doi.org/10.20344/amp.11737
}

\section{ABSTRACT}

Papillary carcinoma of the breast is a rare type of breast malignancy, making up less than $2 \%$ of breast cancers, and only some are encapsulated papillary carcinoma. Usually, EPC are low-grade luminal like tumors. The authors report a case of a 50-year-old female with the diagnosis of an unusual high-grade triple negative encapsulated papillary carcinoma with an area of invasive papillary carcinoma and negative axillary lymph nodes. Considering its rarity, the description of this case and its clinical management are important in order to better understand this entity and choose the best clinical approach.

Keywords: Breast Neoplasms; Carcinoma, Papillary; Lymph Nodes

\section{RESUMO}

O carcinoma papilar é um tipo raro de cancro da mama, com incidência inferior a $2 \%$, sendo apenas uma parte carcinoma papilar encapsulado. Normalmente, o carcinoma papilar encapsulado apresenta-se como um carcinoma da mama tipo luminal e bem diferenciado. Os autores apresentam o caso de uma mulher de 50 anos com o diagnóstico de carcinoma papilar encapsulado triplo negativo e pouco diferenciado com uma área de carcinoma papilar invasivo e gânglios linfáticos axilares negativos. Considerando a sua raridade, a descrição deste caso e da sua abordagem torna-se importante um melhor entendimento desta entidade e para compreender a melhor prática clínica a utilizar.

Palavras-chave: Carcinoma Papilar; Neoplasias da Mama; Nódulos Linfáticos

\section{INTRODUCTION}

Malignant papillary breast lesions are a rare type of breast cancer and are presented as a heterogeneous group of lesions with different histological types, such as, ductal carcinoma in situ arising in an intraductal papilloma, papillary ductal carcinoma in situ, encapsulated papillary carcinoma (EPC), solid and invasive papillary carcinoma (IPC), ${ }^{1}$ occurring mostly during the fifth and sixth decades of life. ${ }^{2}$ EPC, originally considered as an in situ carcinoma, differentiated by the presence of a fibrous capsule and absence of a myoepithelial cell layer, is now seen as an indolent and low-grade invasive carcinoma which rarely metastasizes to axillary lymph nodes ${ }^{1-3}$ without evidence of invasion. ${ }^{4}$ Hormone receptors [estrogen and progesterone receptors (ER ( PR) are usually positive and HER2 negative. ${ }^{1}$ EPC may rarely be associated with invasive carcinoma when the carcinoma extends beyond the fibrous layer. ${ }^{3}$ The authors only encountered four articles reporting high-grade, triple negative EPC with invasive component. ${ }^{5-9}$

\section{CASE REPORT}

A 50-year-old female, previously healthy and with no family history of breast cancer, was referred to a breast surgery clinic for presenting a painless palpable mass on the outer-lower quadrant of the left breast with a month of evolution.

Breast ultrasound and mammography showed a lobulated nodular image of $3.3 \times 2 \mathrm{~cm}$, (BIRADS 4A). Core needle biopsy (CNB) was performed and demonstrated small fragments of fibroadipose tissue and scarce breast parenchyma.

A 6-month follow-up left breast ultrasound and mammography showed a cystic mass with a solid component of $9.1 \times 5.4 \mathrm{~cm}$ (BIRADS 4A) (Fig. 1). Fine needle aspiration cytology was performed, which was negative for cancer cells.

Breast MRI was performed three months later, which showed a voluminous cystic lesion of $12.7 \times 10.5 \mathrm{~cm}$ associated with a solid component and skin thickening on the left breast (BIRADS 4A) (Fig. 2).

Given the growth and volume of the breast lesion, which was discordant with previous histological and cytological findings, an excisional biopsy was performed to clarify the lesion's nature (Fig. 3) (Fig. 4). The histopathological report of the excisional biopsy revealed EPC with $11 \mathrm{~cm}$ of diameter associated with an invasive component of $5 \mathrm{~cm}$, with tumor present in the surgical margins. Tumor cells were

\footnotetext{
* Co-primeiros autores

1. Breast Unit. General Surgery Department. Hospital São Bernardo. Centro Hospitalar de Setúbal. Setúbal. Portugal.

$\bowtie$ Autor correspondente: Xavier de Sousa: xavier.sousa@chs.min-saude.pt

Recebido: 26 de dezembro de 2018 - Aceite: 17 de junho de 2019 | Copyright @ Ordem dos Médicos 2020
} 


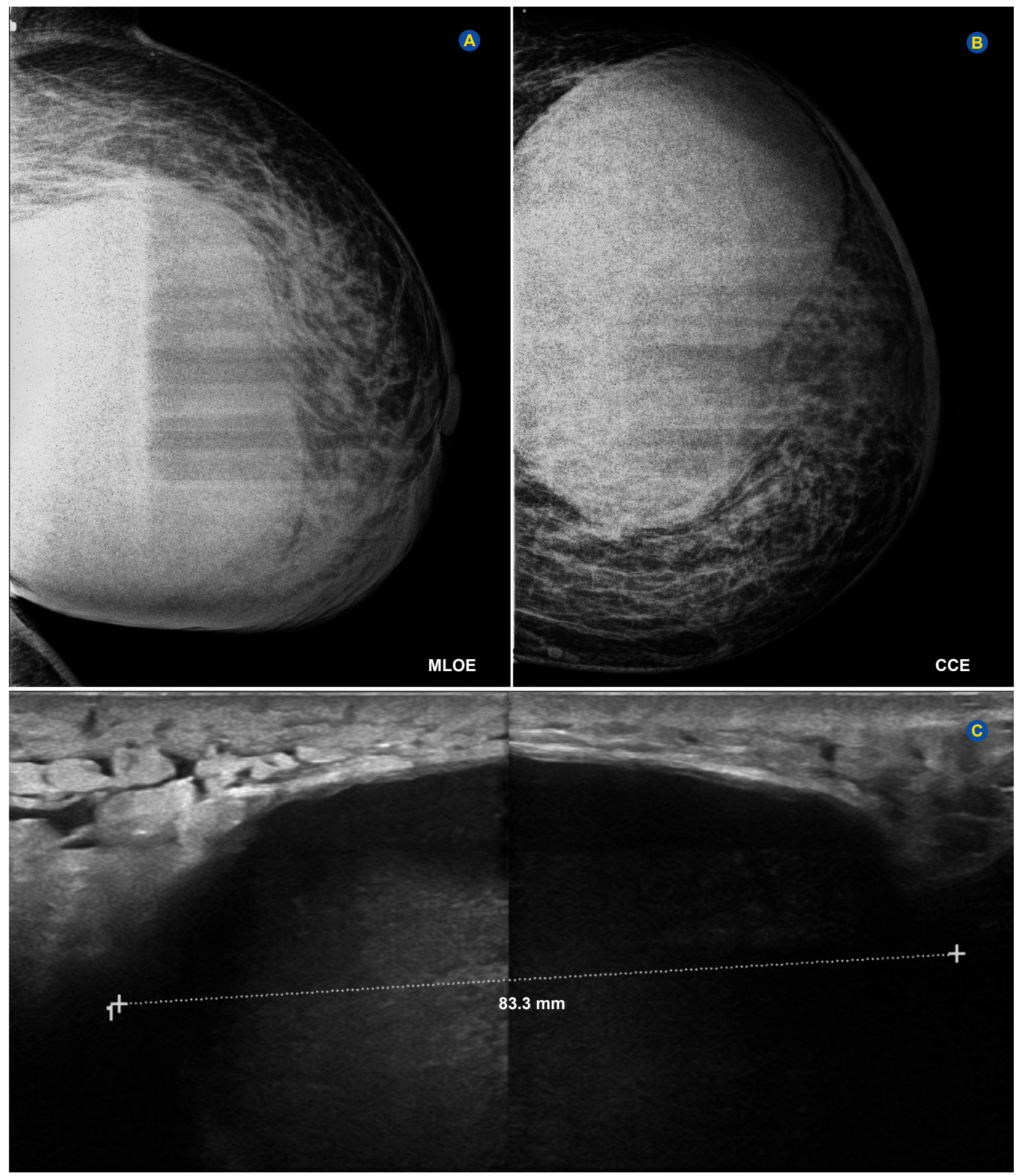

Figure 1 - Mammography

negative for ER, PR and HER2, with a Ki-67 proliferative index of $100 \%$ and positive for CK $5 / 6$ (Fig. 5). In discussion with the attending pathologist, carcinoma with cystic degeneration or IPC simultaneously associated with an invasive carcinoma were suggested as possible differential diagnoses but were promptly excluded by the absence of a myoepithelial circumscribed invasive carcinoma. Pathology staging was pT3 pNx pR1.
Two weeks after the excisional biopsy, the patient underwent left breast mastectomy with sentinel lymph node (SLN) biopsy. The histopathological report of the breast revealed a $1.5 \mathrm{~cm}$ IPC, margins free of tumor and SLN free of metastasis. The final pathological cancer staging was pT3 No.

The patient was referred to the Oncology clinic for followup and adjuvant therapy. She was treated with six cycles 


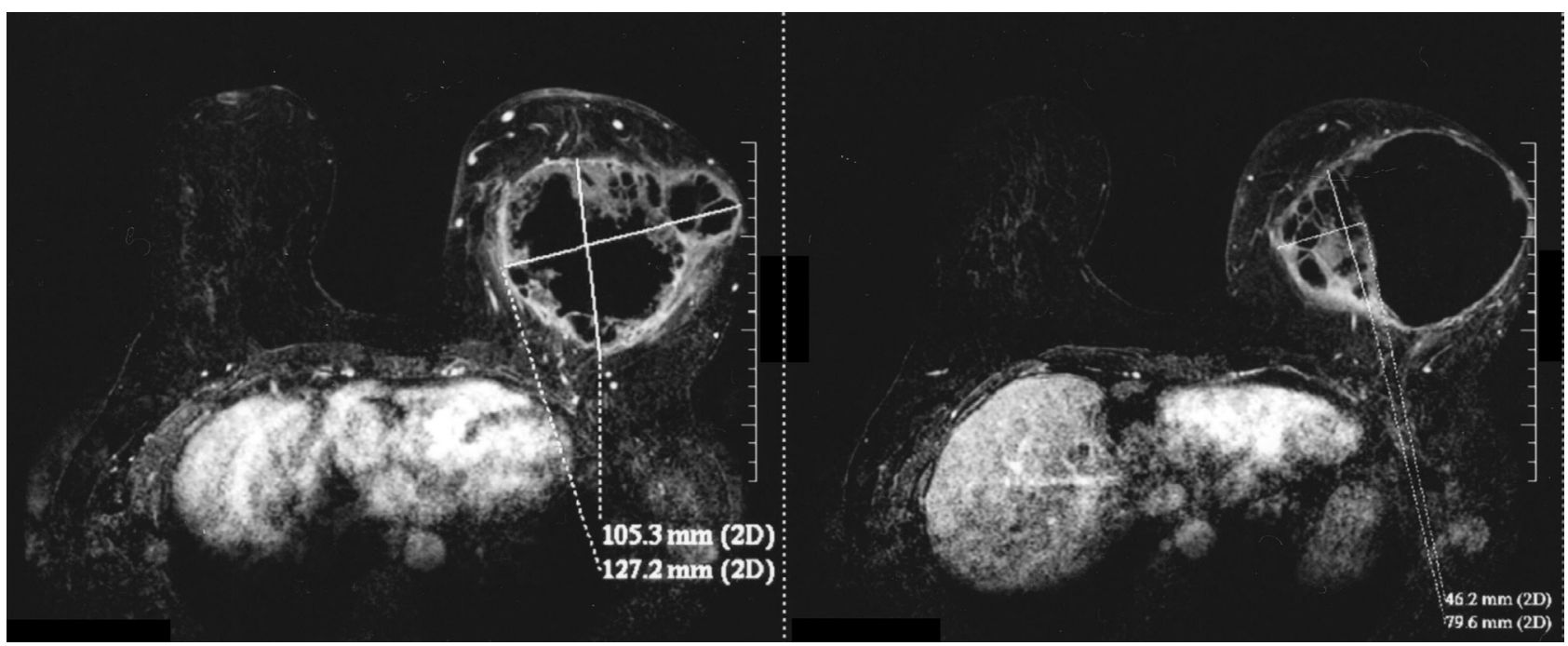

Figure 2 - Breast MRI

of FEC (fluorouracil $500 \mathrm{mg} / \mathrm{m}^{2}$, epirubicin $100 \mathrm{mg} / \mathrm{m}^{2}$ and cyclophosphamide $500 \mathrm{mg} / \mathrm{m}^{2}$ ) and developed chemotherapy induced neutropenia during treatment. After nine months of follow-up the patient developed left cervical and suprasternal lymphadenopathies. The computed tomography (CT) scan demonstrated lithic lesions of the sternal notch and supra and inferior clavicular lymphadenopathies, which were highly suggestive of secondary lesions. The patient began radiation therapy with a dose of $60 \mathrm{~Gy}$ and first line metastatic chemotherapy with docetaxel $75 \mathrm{mg} / \mathrm{m}^{2}$ and carboplatin AUC 6 . Due to hematological toxicity and disease progression only three cycles were carried out, and second line palliative chemotherapy with liposomal doxorubicin 50 $\mathrm{mg} / \mathrm{m}^{2}$ was initiated. As a result of disease progression and treatment failure, only one cycle of palliative chemotherapy was done and the patient was followed in a Palliative Care Unit, and died seven months after the appearance of the first metastases.

After the diagnosis of the EPC as established, all decisions regarding treatment and follow up where discussed in a multidisciplinary team meeting.

\section{DISCUSSION}

Papillary breast carcinomas are a rare type of breast cancer with a heterogeneous group of lesions which includes, among others, EPC and IPC. ${ }^{1,2}$

EPC occurs mostly in post-menopausal women, after the fifth decade of life. ${ }^{2}$ It usually presents as a well circumscribed nodular mass associated with a cyst and surrounded by a fibrous capsule. ${ }^{2}$ Although it is morphologically well delineated with its fibrous capsule having a similar characteristic to in situ tumors, the absence of a myoepithelial cell layer has led some authors to propose it may be a well circumscribed invasive carcinoma ${ }^{1-4,10}$ with an indolent behavior and a favorable prognosis..$^{1-4}$ EPC are typically low or intermediate-grade tumors, although high-grade is rarely

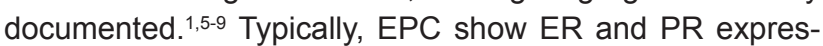
sion. EPC may seldom be associated with an invasive carcinoma component, sometimes with no papillary features. ${ }^{1}$ IPC is only present when the invasive component extends beyond the fibrous capsule.4,10 EPC is known to rarely metastasize, ${ }^{1}$ albeit some authors have described axillary lymph node metastasis. ${ }^{1-3}$ In general, however, there is no universal agreement, so EPC may be staged and managed as an in situ tumor given its indolent nature and good prognosis, ${ }^{1}$ unless there is an associated invasive component or a high grade tumor is diagnosed.

High-grade triple negative tumors may be present in up
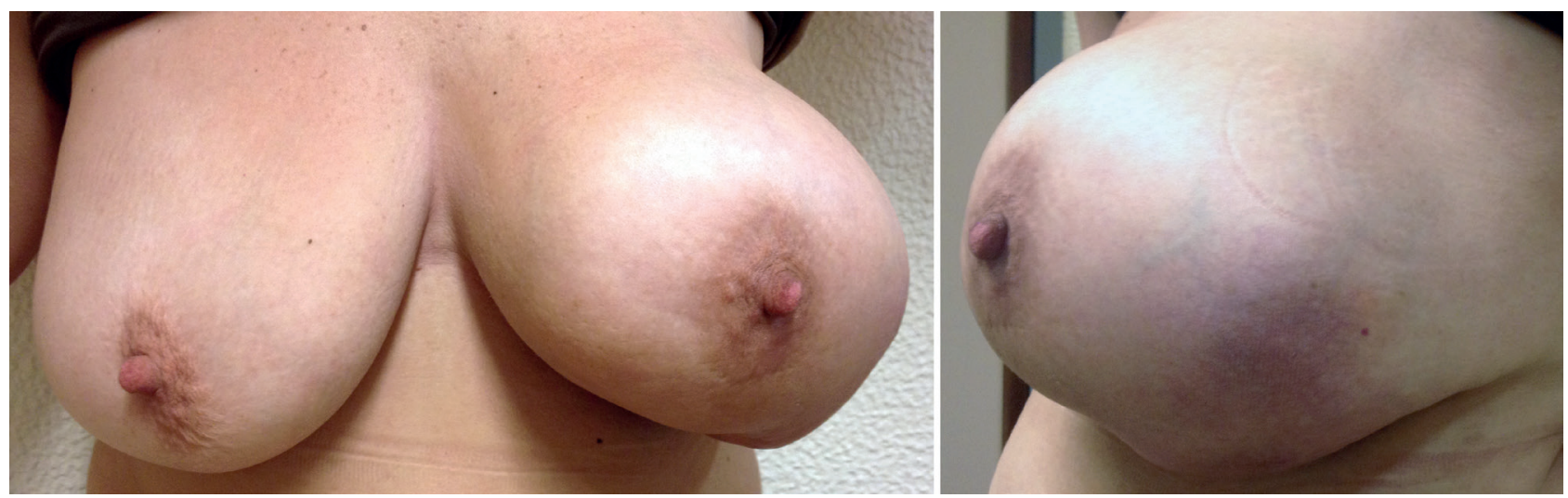

Figure 3- Left breast before excisional biopsy, anterior view 


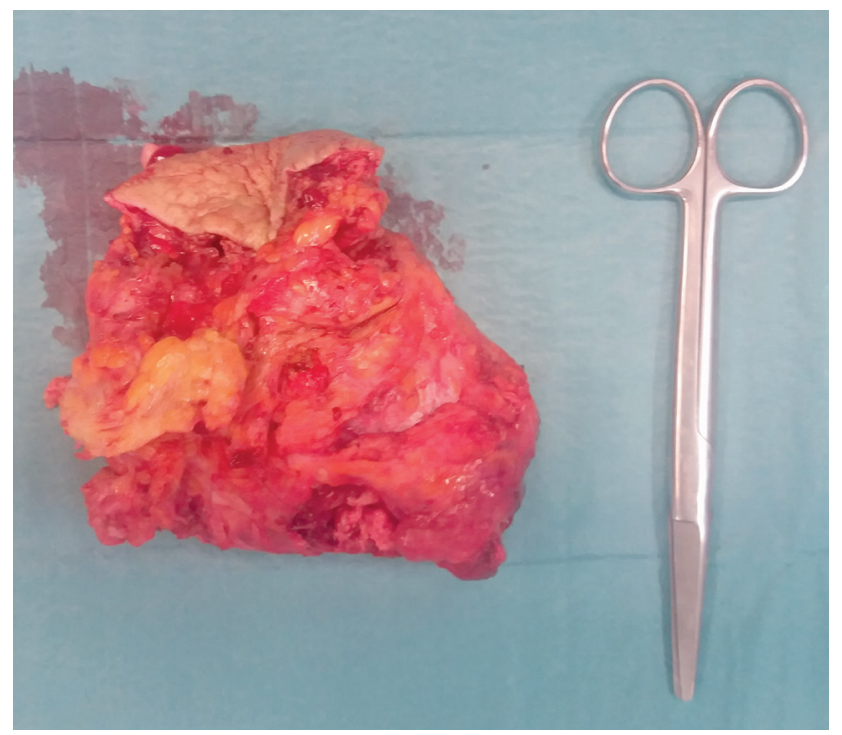

Figure 4 - Surgical specimen of the excisional biopsy

to $3 \%$ of EPC, and are associated with more aggressive features, larger size and higher likelihood of invasion, recurrence, and metastasis. ${ }^{5-7}$

Radiological findings on breast ultrasound for papillary neoplasms are the presence of intraductal mass with or without ductal dilation, intracystic mass or solid pattern with an intraductal mass filling the duct. These characteristics, however, have a sensitivity and specificity for the diagnosis of malignancy of $85.7 \%$ and $64.9 \%$ respectively. Breast magnetic resonance imaging (MRI) presents more limited results, with most papillary lesions being characterized as benign. ${ }^{4}$

A CNB may not properly be able to show if a papillary lesion is malignant or not. Therefore, in the presence of a papillary lesion on CNB, surgical excision should be recommended, especially if there's clinical or histological uncertainty. 4,11

Regarding treatment strategy, there is no definitive guideline for the management of rare types of papillary carcinomas, such as ECP and IPC. ${ }^{4}$ Considering the indolent nature of EPC, surgical excision with tumor free margins might suffice, as in in situ lesions. ${ }^{3,5,7}$ When in the presence of a high-grade triple negative EPC and IPC with metastatic potential, adequate treatment, surgery and adjuvant therapies, are not known. There is lack of literature regarding use of adjuvant therapy in the treatment of EPC with inva- sive carcinoma. ${ }^{5-9}$ When dealing with invasive tumors, SLN biopsy should be performed. 5,6

\section{CONCLUSION}

In this case, we faced diagnostic difficulty due to the unusual presentation of the disease and misleading initial histological and cytological findings.

EPC is a rare entity and little is known when it is associated with the characteristics illustrated in this case - a highgrade triple negative tumor, prone to fast growth, invasion and metastization instead of its usual indolent in situ-like, low-grade tumor behavior. Its proper and most adequate treatment is not yet fully understood.

The description of this case and its clinical approach is important in order to better understand the behavior of these very rare lesions, diagnostic and therapeutic obstacles, and to contribute to improve clinical practice.

\section{OBSERVATIONS}

This clinical case has been presented as a poster at the XVI Jornadas de Senologia, October 2016, Braga, Portugal.

\section{PROTECTION OF HUMANS AND ANIMALS}

The authors declare that the procedures were followed according to the regulations established by the Clinical Research and Ethics Committee and to the 2013 Helsinki Declaration of the World Medical Association.

\section{DATA CONFIDENTIALITY}

The authors declare having followed the protocols in use at their working center regarding patients' data publication.

\section{PATIENT CONSENT}

Signed consent was obtained from the patient.

\section{CONFLICTS OF INTEREST}

All authors report no conflict of interest.

\section{FUNDING SOURCES}

This research received no specific grant from any funding agency in the public, commercial, or not-for-profit sectors.

papillary carcinoma of breast with invasive component. J Clin Exp Pathol. 2017;7:2.

6. Chauhan K, Garg M. An unusual case of encapsulated papillary carcinoma of breast. J Cancer Metastasis Treat. 2016;2:224-7.

7. Rakha EA, Varga Z, Elsheik S, Ellis IO. High-grade encapsulated papillary carcinoma of the breast: an under-recognized entity. Histopathology. 2015;66:740-6.

8. Terzi A, Uner AH. An unusual case of invasive papillary carcinoma of the breast. Indian J Pathol Microbiol. 2012;55:543-5.

9. Kuroda N, Ohara M, Inoue K, Mizuno K, Fujishima N, Hamaguchi N, et al. The majority of triple-negative breast cancer may correspond to basal-like carcinoma, but triple-negative breast cancer is not identical to 
basal-like carcinoma. Med Mol Morphol. 2009;42:128-31.

10. Pal SK, Lau SK, Kruper L, Nwoye U, Garberoglio C, Gupta RK, et al. Papillary carcinoma of the breast: an overview. Breast Cancer Res Treat. 2010;122:637-45.
11. Sousa X, Ferreira PS, Branco L, Simões J, Gonçalves M, Rigueira MV et al. Neoplasm of uncertain behaviour of the breast-a retrospective study in a breast unit. Ecancermedicalscience. 2018;12:839. 